\title{
15. An update on fiscal reform
}

\section{Christine Wong}

In my chapter for the 2013 volume of the China Update, I described the evolution of China's system of public finance from the start of market transition, summarising progress to date and pointing to some of the remaining problems (Wong 2013b). It seems appropriate and timely for my chapter in this volume to focus on changes over the past five years-a period neatly bookended by the extensive reform package announced at the third plenum of the eighteenth Communist Party Congress in November 2013, and the latest reforms announced by the just-concluded nineteenth party congress. As it happens, these five years have been highly consequential in the reform of China's fiscal system and, although it is much too soon to know how the latest changes will play out, the direction of reform points to even more significant changes ahead, especially in central-local government relations.

One year after assuming the top leadership post in November 2012, Chinese President Xi Jinping rolled out a sweeping program of reform that was endorsed by the third plenum of the eighteenth party congress. The 60-point 'Decision on Several Major Questions about Deepening Reform' (Xi 2013) spells out an ambitious, comprehensive agenda of more than 300 reform initiatives that cover virtually every facet of Chinass economy, society and government, including reforms of the fiscal and financial sectors, state-owned enterprises (SOEs), land and property rights, liberalisation of factor prices, household registration, family planning and judicial and administrative reforms. In his 'explanatory notes' on these decisions, President Xi identified the reform of public finance as among the top three key issues to be addressed, noting that '[p]ublic finance is the foundation and important pillar of state governance' (Xi 2013).

Fiscal reforms were off to a rapid start under the energetic direction of then finance minister Lou Jiwei, who announced a comprehensive program that was to proceed in three phases. The first phase - to begin immediately - would focus on budget and public financial management reforms; phase two would begin in 2015 with a focus on reforms of the tax system; and phase three would begin in 2016 and focus on intergovernmental fiscal reform (Han et al. 2014).

Writing in the Communist Party journal Qiushi, Lou explained that China's fiscal system has not kept pace with the needs of its growing and increasingly complex economy: 
[T] he defects have become increasingly apparent: the budget management system is not standardized, transparent, or suited to the requirements of modern governance; the tax system ... is not conducive to supporting the shift to the new development paradigm, ${ }^{1}$ social fairness, or market integration. The division of responsibilities between the central and local governments is unclear and unreasonable ... These problems ... affect not only the stability and sustainability of the fiscal system itself, they also [adversely] affect the national development strategy and the effectiveness of macroeconomic policy. (Lou 2014)

Lou (2014) argued that, 'in this round of reform, small patches and fixes will no longer suffice', and fundamental reform of the fiscal system was needed to build the foundation to support the modernisation of governance called for by the decisions of the third plenum.

Party and legislative support came swiftly. In June 2014, the Politburo approved the program for comprehensive deepening reform of the fiscal system. In August 2014, the Standing Committee of the National People's Congress approved the revised Budget Law, which mandates numerous changes and, for the first time, authorises local governments to borrow money for capital investments (NPC Standing Committee 2014). These were followed with numerous State Council directives providing detailed guidelines for implementation-for example, both Document 43 on local government debt issuance and Document 45 on deepening budget reform and shifting to medium-term budgets came in September 2014, and Document 63 on building an accrual-based financial management system and Document 71 on improving the structure of expenditures and cleaning up transfers came in December 2014.

After 2014, the momentum of reform appears to have slowed significantly, with few legislative achievements. Little progress was made in tax reform. Of the three areas identified by Lou Jiwei, only the replacement of the business tax with the valueadded tax (VAT) was completed; few changes have been made to resource taxes, and the much-discussed property tax is still awaiting submission to the National People's Congress. As for intergovernmental reform, although preparatory work began in early 2014, when provinces were asked to prepare proposals for the revision of expenditure assignments, ${ }^{2}$ no concrete measures had been put forward before Lou retired as finance minister in November 2016. With the loss of its most forceful and vocal advocate, the fate of deep fiscal reform appeared more tenuous as Xi Jinping's first term drew to a close.

1 As early as 2002, the government announced its goal of shifting to a development paradigm that promotes services and consumption in place of industry and investment (Wong 2010).

2 Fieldwork information, June 2014. 
In this chapter, I trace the progress of reforms introduced since the third plenum (hereinafter referred to as the third plenum reforms) and argue that substantial progress has been made in building a framework for budget and public financial management that will provide strong support for the next phase, especially for intergovernmental reform. More importantly, the reforms have changed some incentives for local governments that have set in motion a new dynamic that should gradually clarify the boundary between the state and the market. However, some key aspects of the reform have to date been subverted-most notably, the effort to contain and manage local government debt, which was thwarted by a combination of political, institutional and economic factors.

Section two of this chapter provides a brief background of fiscal reforms over the past four decades and the problems leading up to the third plenum. Section three sets out the key measures of fiscal reform introduced since 2013, while section four assesses their implementation progress to date, focusing on changes in government financial reporting and transparency. Section five summarises and offers some concluding remarks on the prospects for fiscal reforms overall and on intergovernmental fiscal reform during Xi Jinping's second term.

\section{Background to the third plenum fiscal reforms}

In the course of transition over the past 40 years, China has had to completely rebuild the system of public finance and associated institutions-from the tax system to tax administration and budget management (Wong and Bird 2008; Wong $2013 \mathrm{~b}$ ). To date, the process has been incremental and reactive, aimed principally at 'putting out fires'. To stem the sharp fiscal decline caused by the dismantling of planning mechanisms that eroded state-owned enterprise profits - a primary source of government revenues in the old system-reforms focused first on rebuilding the government's revenue mechanism. ${ }^{3}$ In 1994, a new system of taxes was put in place under the Tax Sharing System reform, which installed VAT, a business tax, a corporate income tax, a personal income tax and several taxes on the transactions of property and land. Though far from ideal, the tax system provides broad-based taxes and is highly income-elastic, and has produced buoyant revenues that grew at almost 1.5 times the rate of GDP through the first decade of this century.

With revenues recovering, the government turned in the late 1990 s to financial management reform. A broad package was introduced that included new procedures for budget preparation and approval, and strengthened budget reporting to the National People's Congress. A new budget classification system was rolled out in

3 On the eve of reform, nearly 80 per cent of government revenue came from state-owned enterprises in industry (Wong 1993). 
2006 to improve the tracking of expenditure by functional categories. Departmental budgets were introduced to clearly identify all resources and expenditures for each government department; the first step toward holding spending units accountable for the public monies they receive. Standardised procedures for government procurement were introduced, and a treasury single account was created to manage the government's cash receipts and payments. With these reforms, China had begun to put in place the basic infrastructure for a modern system of budget management.

A glaring omission in the reforms was the neglect of changes needed to repair intergovernmental fiscal relations, which had been eroded through the fiscal decline of the 1980s and decisively broken in 1994, when the Tax Sharing System abruptly recentralised the share of revenues without adjusting expenditure assignments. Since 1994, expenditure shares have continued to shift downward to local governments, who account for more than 85 per cent of total budget expenditures today while collecting only half the revenues, and are thus heavily dependent on central government transfers to finance the huge fiscal gap. The distortions created by this dysfunctional intergovernmental system have long been considered key sources of inefficiency in the Chinese economy (World Bank 2002, 2007; Wong passim).

Despite the urgency of intergovernmental fiscal reform though, its prerequisite is the completion of reform of public financial management begun in the late 1990s. This is highlighted by a brief review of the decade preceding the third plenum decisions. Hitting its stride after joining the World Trade Organization (WTO) and riding the wave of an exceptionally buoyant global economy up to the Great Crash of 2008, the Chinese economy grew at double-digit annual rates during the period 2000-12. Government revenues grew even faster, at an annual rate of 22 per cent, and growing revenues allowed for a robust expansion of government. Under the banner of creating a 'harmonious society', many new programs were introduced aimed at improving public services and expanding the social safety net to include rural citizens (Wong 2010, 2016). Many of these programs are huge: the move to provide free rural education covered some 150 million students at the outset in 2006, although the number had fallen steeply to fewer than 100 million by 2013 (MOE 2016). The rural cooperative medical scheme is even bigger-covering more than 830 million participants at its peak-and the basic pension scheme covers more than 500 million people. These programs have added enormous costs to the budgets of the counties and districts-the administrative level responsible for the provision of these services. As a result, the county-level (tier four) share of national budget expenditures jumped from 26 per cent in 2000 to 46 per cent in $2013 .{ }^{4}$

4 Author's calculations from Ministry of Finance (MOF) statistics. 
Because these huge programs were rolled out without any significant adjustment to intergovernmental revenue-sharing arrangements, the added expenditure had to be met largely with transfers to county governments. Central government transfers to local governments grew from RMB246 billion in 2000 to RMB4.3 trillion in 2013. Of these, 74 per cent went to the county level, whose fiscal gap had grown to an aggregated total of RMB3.16 trillion! ${ }^{5}$

This created several problems: first, the proliferation of programs led to an even greater proliferation of transfer programs, many of them earmarked. For example, there are at least half a dozen earmarked transfers for rural basic education, along with four to five categories of general transfers designed to support salary payments for teachers, calculated on various bases - and this is just at the central government level. ${ }^{6}$ In China's fiscal system, these transfers have to be passed down through the administrative hierarchy level by level-from Beijing to the provinces, from the provinces to the municipalities and from the municipalities to the counties and districts. As they moved down through the hierarchy, earmarked grants were often divided further into finer categories as each administrative layer tried to target funds to where they were needed. By the time the funds reached the county level, there had sometimes been more than a dozen transfers just for basic education. ${ }^{7}$ The earmarking was often ineffective (Liu et al. 2009), and the administrative burden of managing them created an extraordinary strain on the bureaucracy, far outstripping the capacities of the monitoring and supervisory systems (World Bank 2007). ${ }^{8}$ While the new programs have expanded public services and brought many benefits, they have been marred by pervasive wastefulness, program capture, cost inflation and even the appearance of 'ghost teachers' and 'ghost schools'.'

The neglect of institutional reform was even more problematic in the cities, with the urban population growing from 191 million in 1980 to 731 million in 2013 (Wong 2013a, 2013b). Amid the steep fiscal decline in the 1980s through to the mid-1990s, the government had few resources to devote to urbanisation. To avoid hindering growth, political leaders tolerated and tacitly encouraged the use of informal, backdoor practices that enabled cities to obtain the resources needed for investment in infrastructure; China's municipalities grew and prospered by relying overwhelmingly on extra-budgetary resources-mainly land sales and offbudget borrowing (Wong 2009, 2013a). Even through the recent fiscal expansion, these practices continued and ratcheted up in intensity, operating largely beyond

5 Equal to 20 per cent of total expenditure in 2013.

$6 \mathrm{MOF}$ and fieldwork information.

7 Fieldwork information, 2006-07.

8 For the history of how systems of accountability were weakened by the dismantling of the planned economy and the subsequent long fiscal decline, see Wong (2009). For weaknesses of the systems of monitoring and evaluation, see Wong $(2012,2013 \mathrm{a})$.

9 See World Bank (2007) and Fock and Wong (2008) for problems of rural public finance and service delivery, and Lin and Wong (2012) for examples of problems in the design and distribution of rural subsidies. 
government financial oversight. ${ }^{10}$ The easy access to money from land and borrowing, in an economy that was expanding at double-digit rates, led inexorably to excessive land takings, overdevelopment, urban sprawl and the creation of excess capacity in industry as cities competed for job-creating investment to raise land values. These activities also brought graft and corruption on an unprecedented scale, and left many cities with unsustainable levels of debt.

Many of the provisions in the fiscal reform package laid out in 2014 were aimed at correcting the problems just described: to build a more efficient framework for service delivery in a multilevel system and to rein in local government debt and extra-budgetary revenues and regain macroeconomic oversight over fiscal activities. Great emphasis was put on improving budget transparency and accountability by strengthening the legal foundations and giving the national and subnational people's congresses greater oversight authority. Intergovernmental reform aimed to clarify and realign revenue and expenditure assignments to reduce reliance on transfers, and tax reform aimed to reduce allocative distortions and make tax a more effective tool for supporting structural reforms of the economy and improving distributional outcomes.

Given the severity of the problems of local government debt and the extent of extrabudgetary financing, all efforts during the early phase of reform were focused on public financial management (PFM) reforms and regaining control over the budget and allocative processes, to establish the accountability mechanisms needed to support an improved intergovernmental fiscal system that would come later.

\section{The third plenum reforms}

By far the most important step in the fiscal reform package was the rollout of the revised Budget Law in August 2014, which laid the legal foundation for improving the budget process, codifying many aspects of central-local government responsibilities and building a robust system of PFM. Among its key provisions are stipulations for shifting to a medium-term budget framework to focus on expenditure planning and multiyear budget balancing, away from the rigidity of annual budget balancing and the associated pro-cyclical bias.

The law calls for budget reporting to be comprehensive, going beyond the traditional reporting of on-budget revenue and expenditure to include three additional components: the 'government fund budget', comprising the extra-budgetary and earmarked levies that were formerly called 'extra-budgetary revenues', the biggest piece of which is revenue from land sales; the 'state capital budget', comprising

10 For an early account of how the central government was kept largely in the dark on the development of local government financial vehicles (LGFVs) and the extent of local government borrowing, see Wong (2011). 
remittances from SOEs; and the 'social security fund budget', comprising receipts and expenditures for pension and social insurance schemes. While the Budget Law requires the joint reporting of the four budgets, it stops short of calling for their consolidated management and allocation.

In a press conference held just after the Budget Law's passage, then finance minister Lou explained that budget transparency is paramount for combating corruption and stemming it at the source. The new Budget Law sets disclosure requirements for the scope, timing and content of comprehensive government financial reporting, not only for the four budgets, but also for selected key items, including transfer payments, government debt and departmental budgets for spending units. It also specifies legal liabilities for the breach of these budget disclosure norms (Article 92).

To ensure the accuracy and comprehensiveness of the information provided, the law specifies that budget reporting be based on accrual accounting to reflect the true operations, financial status and financial sustainability of government in the medium and long terms (Article 79). This mandate to adopt accrual accounting was endorsed by the State Council four months later, when it issued its 'Reform plan for building the comprehensive financial reporting system using accrual accounting' (Document 63) (State Council 2014b). Together, the Budget Law and Document 63 essentially committed the government to creating a new system of financial reporting. Indeed, Document 63 was ambitious in calling for the establishment by 2020 of the four systems: the government accounting system, the government financial reporting system, the system of auditing and disclosure mechanisms for government financial reports and the system for analysing and applying the information from government financial reporting to improve budget outcomes.

Another critical change under the Budget Law is the authorisation given to provincial governments to borrow through the issuance of provincial government bonds, with tight supervision by central and provincial people's congresses. Under the call to 'open the front door, lock the back door', the Budget Law stipulates that local governments must report on the amount and mode of debt and its purpose, as well as specifying the repayment sources, mechanisms of supervision and legal liabilities (Articles 35 and 94). Detailed guidelines for a debt management system are laid out in State Council Document 43, which ordered local governments to classify and report all outstanding debt by the end of 2014, and assigned to provinces the key role of registering and monitoring this debt (State Council 2014a). It prohibited local governments from borrowing through enterprises or local government financial vehicles (LGFVs) and required that existing LGFVs be separated from local government finance. In addition, the document laid out an ambitious plan to tackle the stock of existing debt by swapping existing bank loans with provincial government bonds. 


\section{Progress in implementation}

It is not possible in this short chapter to provide a comprehensive review of implementation progress for the third plenum reforms. In this section, I will focus on three key areas: the process and pace of introducing the new system of government financial reporting, progress in increasing the transparency of reporting of government accounts and progress in building a system for managing and containing local government debt.

\section{Government financial reporting}

The purpose of accrual accounting is to provide more accurate and comprehensive information on government financial outcomes, including government assets, liabilities, revenue, expenses and cash flows. The new government financial reporting system (GFRS ${ }^{11}$ is expected to form an important part of the foundation for building a modern system of fiscal management that will promote sustainability and good governance. From the start, the Ministry of Finance (MOF) made clear that the new GFRS would be built on international standards modified to fit China's conditions.

Because the new GFRS will be so different from previous financial reporting practices, building this new system will be a complex project with many stepsfrom extending the scope of reporting to adopting accrual accounting standards, developing standardised accounting rules, building a balance sheet that includes all entities with claims on public resources and establishing an integrated information system linking all reporting entities. In many countries that have adopted accrual accounting, the process of building the system took up to a decade of sustained effort (Liu et al. 2015). In China, the size and difficulty of the project are magnified many times by the large size of the country and the highly decentralised fiscal system, where the GFRS has to be adopted by subnational governments down to the county and district levels - a group that includes more than 3,200 budgeting authorities with widely varying capacities. ${ }^{12}$

Identifying the reporting entities is among the first critical tasks in building the GFRS. According to the principle that government financial reporting must include all entities that have a material impact on the government's fiscal position, international standards call for the inclusion of all SOEs as well as LGFVs that meet

11 To distinguish this new system in China from the Government Financial Statistics (GFS) system widely adopted internationally, this chapter will refer to the Chinese system of government finance reporting as the GFRS.

12 Budgeting authorities include 31 provincial governments and five cities with 'line item' status (Shenzhen, Dalian, Qingdao, Ningbo and Xiamen), more than 300 prefectural level governments, 2,850 counties and districts and, of course, the central government itself. 
the control criteria. ${ }^{13}$ Given the large number and size of SOEs in China, including their impact on government finances will be an important corrective to what has long been a blind spot in budget reporting.

There are different ways of including the enterprises depending on the nature of their interaction with the budget. SOEs that are strictly market-oriented and have only an arm's-length relationship with government can be included as commercial enterprises. They must file an annual report with the government disclosing their operations and financial status, but their assets and liabilities need not be included in the government balance sheet. Enterprises that have close, recurrent financial interaction with government would be classified as government business corporations, and their accounts must be fully consolidated in the government financial statement. The differing reporting requirements for the two types of enterprises are briefly summarised in Table 15.1 .

Table 15.1 Classification of SOEs and their reporting in the GFRS

\begin{tabular}{|c|c|}
\hline \multicolumn{2}{|c|}{ SOES } \\
\hline $\begin{array}{l}\text { Government business corporations } \\
\text { ('Public benefit' SOEs) }\end{array}$ & Commercial SOEs \\
\hline $\begin{array}{l}\text { - Full disclosure. } \\
\text { - Fully consolidated in government financial } \\
\text { statements. } \\
\text { - Included in government's statements of } \\
\text { operations, cash flow and balance sheets. }\end{array}$ & $\begin{array}{l}\text { - Full disclosure in a separate schedule } \\
\text { in government financial report. } \\
\text { - Assets and liabilities are not included } \\
\text { in government balance sheet. } \\
\text { - Net assets are recognised as government } \\
\text { investment in government balance sheets. }\end{array}$ \\
\hline
\end{tabular}

The first big challenge for the GFRS reform is to collect financial information from SOEs as the basis for their classification as well as for recording. This is not as straightforward as it seems. Until now, enterprise information has been collected not by budget departments but by the State-owned Assets Supervision and Administration Commission (SASAC) and other supervisory agencies, with each agency using a different methodology for counting; there seems to be no agreed set of numbers. This is illustrated by the situation in Beijing Municipality. As shown in Table 15.2, data from four authoritative sources give significantly different statistics on the number of enterprises and their financial statistics.

13 This is true for both the International Monetary Fund's (IMF) GFS and the International Public Sector Accounting Standards (IPSAS). IPSAS determines that a government controls an entity if it meets the three criteria: 1) power over the entity (such as voting rights, the right to appoint senior management and to approve or veto the entity's business decisions); 2) exposure, or rights, to variable benefits (financial or nonfinancial) from its involvement with the entity; and 3) the ability to use its power over the entity to affect the nature or amount of the benefits from its involvement with the other entity. 
Table 15.2 Differing counts of SOEs in Beijing Municipality, 2013 (RMB billion)

\begin{tabular}{|l|r|r|r|r|r|r|}
\hline & $\begin{array}{r}\text { Number of } \\
\text { enterprises }\end{array}$ & Total assets & Total debt & \multicolumn{1}{c|}{ Equity } & \multicolumn{1}{c|}{$\begin{array}{l}\text { Operating } \\
\text { revenue }\end{array}$} & \multicolumn{1}{c|}{ Profits } \\
\hline A & 790 & $2,333.5$ & $1,202.1$ & $1,131.4$ & $1,068.0$ & 70.9 \\
\hline B & 549 & 573.3 & 458.6 & 395.7 & 436.2 & 33.1 \\
\hline C & - & $2,520.9$ & $1,724.5$ & 796.4 & 949.9 & 47.2 \\
\hline D & 7,040 & $3,513.5$ & - & $1,098.6$ & $1,106.6$ & 65.3 \\
\hline
\end{tabular}

- no data

Sources: Row A from NBS (2014: Table 13-4); B: BMBS (2014: Table 11-8); C: Beijing Municipal SASAC (2015); D: MOF (2014: 605-6).

One reason for the differences may be that some of the data refer to all SOEs, while others refer only to SOEs above a specified minimum size; however, a more significant reason for the conflicting numbers may be the complex ownership and control structures that characterise many SOEs. To illustrate, in 2015, there were 46 SOEs that reported directly to the Beijing Municipal SASAC, but most of these were actually enterprise 'groups' comprising many subsidiary companies, so that the number of municipal-owned SOEs was many multiples of 46. For example, the Beijing Municipal Drainage Group (one of the 46) had 28 subsidiaries that engaged in different parts of the water business, from supplying fresh water to disposal of waste water and pipeline management-many of them independent legal entities. ${ }^{14}$ For complex enterprises like this, the classification exercise will likely have to go to the subsidiary level.

To complicate matters further, many SOEs engage in some public goods provision alongside their market activities. For example, the Beijing Municipal Infrastructure Investment Corporation is responsible for the financing and construction of subways - a task that has clear characteristics of being a public good-but it also owns 11 subsidiary companies that engage in for-profit land and real estate development, and the extent to which these activities cross-subsidise one another is unrecorded.

Given the pervasive lack of a clear boundary between the public and the market, financial interactions between governments and SOEs are often fuzzy and complex. In these circumstances, a strict application of the International Public Sector Accounting Standards (IPSAS) and Government Financial Statistics (GFS) rules might require the full inclusion (with line-by-line consolidation of their financial status) of a huge portion of SOEs in the GFRS, which would impose an impossible task for quick adoption. In addition, there are some 660,000 public institutions, such as hospitals, universities, research institutes and so on, that provide public services at the behest of government but also have business incomes, and whose 
financial relationship with government will require sorting through. To keep the task to manageable proportions, the interim solution-at least until 2015-has been for many local governments to classify all SOEs as commercial and focus on classifying their LGFVs. ${ }^{15}$ In some localities the exercise morphed to simply classifying profitable enterprises as 'commercial' and unprofitable ones as 'public benefit' and putting the latter on the budget. ${ }^{16}$

Unresolved issues in classification notwithstanding, other preparatory work has been proceeding on the GFRS. In November 2015, the MOF issued a document on government financial reporting methodology that laid out plans for determining the scope of the trial effort. The plans called for the development of government financial information systems and training to be conducted in 2016, and, beginning in 2017, compilation of the pilot GFRS (MOF 2015b). In March 2018, the MOF officially launched a pilot program for compiling government financial reports for the 2017 fiscal year using accrual accounting. In this phase, the pilot involves 20 central government agencies and 20 provinces or line item cities, and focuses only on the budgets of the pilot agencies, rather than the whole government (MOF 2018b). Those involved in the pilot are to follow the 140-page trial 'Guidelines for the Preparation of Financial Reports for Government Departments' (MOF 2018a).

The work on construction of a government balance sheet also appears to be progressing. Led by the National Bureau of Statistics (NBS), working with 10 other agencies including the National Development and Reform Commission (NDRC), pilot work was conducted from May 2015 to the end of 2016 in 11 provinces. A draft 'Work Program for National and Local Balance Sheet Preparation' was circulated for comment and was signed off in April 2017 by 13 ministries and sent to the State Council. In June of that year, it was approved at the thirty-sixth meeting of the Central Leading Group for Deepening Reform, and formally issued by the State Council on 6 August 2017, launching the next phase of the work (Xinhua 2017a). However, this document has not been made publicly available. It has been widely reported that a trial national balance sheet was constructed for 2013 but has also not been published (see, for example, 21st Century Economic Herald 2017).

\section{Budget transparency}

While the progress of building the GFRS has been largely invisible to the general public, the remarkable progress in budget transparency has been much more visible and quantifiable. In just three years since the Budget Law laid down a mandate to release government financial reports to the public, every subnational government down to the county level has set up a website from which a trove of fiscal information

15 Fieldwork, June 2015.

16 Fieldwork, June 2016. 
can be harvested by anyone with access to a computer or smartphone. This is in marked contrast with previous attempts to promote budget transparency-most notably in the earlier rounds of PFM reform in the late 1990s and mid-2000s, when there was little follow through and virtually no penetration to the subnational levels (Wong 2005; Liu 2017). Disclosure requirements are now codified and written into the Budget Law. Article 14 stipulates that governments at all levels must disclose their budgets to the public within 20 days of approval by the people's congress, and the disclosure 'shall explain important matters such as the receipt and uses of transfer payments and debt issuance'. Disclosure requirements are also applied to the budgets of government departments as well as to government procurement. The law also calls for budgets to be audited and for the audit reports on budget execution to also be made public (Article 73). Finally, Article 92 stipulates that failure to meet transparency requirements will trigger corrective action and an investigation into the administrative responsibilities of managers.

Monitoring and enforcement have followed. The MOF's Supervision Department issued a notification on 20 October 2015 announcing the first inspection would take place between 28 October and 20 November 2015. The stated purpose was to check compliance with the Budget Law's requirements for timeliness, completeness, level of detail and information disclosure (MOF 2015a). The inspection covered 258,296 budget units at the provincial, municipal and county levels, achieving 100 per cent coverage. It found compliance rates of 100 per cent at the provincial and municipal levels and 99 per cent at the county level for disclosures of both the 2015 budgets and the 2014 final accounts, but somewhat lower rates for disclosure of departmental budgets and provision of the required content (MOF 2016a).

On the basis of these findings, the MOF issued two documents in 2016 to provide further guidance on the scope of public disclosure. Document 123 stipulated that all local governments set up a unified online platform to disclose their budgetary information, and to include budget disclosure as an additional indicator in the performance evaluation of staff in local finance departments (MOF 2016b). Document 143 ('Operating Procedures for Local Government Budget Disclosures') provides more specific requirements: disclosures must cover all four budgets, with a minimum of six tables for the general budget, four tables for government funds and two each for the state capital budget and the social security fund budget (MOF 2016c). In 2016, an additional criterion was added to check for honesty, with inspectors urged to randomly select units and figures for verification, and to include their findings in the overall scoring.

Three rounds of nationwide inspections have been undertaken, including the third one concluded in December 2017 (Liu 2017). This monitoring effort and the change of incentives are clearly producing results. My own casual perusal of local budget reporting on government websites reveals a growing wealth of fiscal information that is now available online. 
Local budget disclosures tend to follow the pace set by the MOF with some lag. For example, in 2009 the MOF provided 61 lines of detail in the final account of budget expenditures. In 2010, it moved to providing 1,020 lines of detail, and the number has since crept up to close to 1,100 lines. Many, but not all, local budget reports follow this template in providing detailed breakdowns of public expenditures running up to 1,000 lines or more. As required, they all contain information on transfers, both inflows and outflows, and all four budgets are provided and comply with the stipulated numbers of tables for each.

To date, these budget reports are still constructed under the old accounting system and on a cash basis. Detailed budgeting is quite advanced on the public finance budget (which used to be called in-budget), but less so on the government fund budget, and even less so on the state capital budget and the social security budget. As expected, the quality of reporting differs across regions, and is higher in the richer, more developed provinces than in the poorer, inland ones. At present, while the budgets are all available publicly, finding them is not always straightforward due to a lack of uniformity in where the information is placed, with budgets sometimes scattered across different websites or in different places within websites. The reporting format and content continue to differ across regions and administrative levels. With the increasingly stringent reporting requirements being implemented, these differences can be expected to shrink over time.

Indeed, this may already be changing. On 6 November 2017, Jiangsu officially launched the 'Jiangsu Budget and Final Accounts Open Access Platform', becoming the first province in China to provide a province-wide platform that includes all local government budget reporting. Developed and built by the provincial finance department and the government service office, the platform aims to provide a centralised portal from which all provincial-, municipal- and county-level budgets and final accounts information can be accessed by the public, and where all reports will use the same templates and uniform standards (Xinhua 2017b).

\section{Managing and containing debt}

The thrust of the reform effort in managing local government debt was to ameliorate the default risks from the large existing stock while moving local government borrowing from hidden, off-budget channels into the open, nudging local governments towards a more fiscally sustainable path.

Key provisions of the Budget Law were designed to put in place mechanisms for preventing unsupervised borrowing by local governments. For the first time, they are explicitly permitted to borrow, but under tight control. Article 35 stipulates that local governments can borrow only under quotas from the cap set by the National People's Congress and allocated by the State Council, and only for capital spending, 
with the use, repayment and assignment of responsibilities supervised by the local people's congresses. The borrowing must be done through bond issuance by the provinces, which are assigned responsibility for allocating and monitoring the debt. Local governments are prohibited from borrowing through any other means or organisations, and from providing guarantees for borrowing by state entities. Article 94 stipulates that any diversion or misuse of funds is punishable by dismissal of those responsible.

Under State Council Document 43, a plan was laid out to tackle the stock of existing debt and create a structure for managing it (State Council 2014a). Along with the Budget Law, this document prohibited LGFVs borrowing on behalf of local governments and ordered them to delink their finances from local government. All existing debt was to be classified as 'general', 'project' or 'enterprise' debt. All general and project debt would be moved to the government's accounts, and many LGFVs would be converted to SOEs. A national registry and an early warning system for local government debt would be built. A program was introduced in 2015 to swap government bonds for local government bank debt. By the end of 2017, RMB10.5 trillion in bonds had been swapped, significantly improving the term structure of local debt and reducing its servicing costs (NAO 2017).

Judging by the outcome of curtailing local government borrowing and keeping it within legal channels, these reform efforts have been a dismal failure. First, rather than fading into history, LGFVs have continued to flourish. World Bank staff estimated the total liabilities of LGFVs (in both bank credit and bonds) grew at more than 20 per cent per annum in both 2015 and 2016, surpassing the growth of overall corporate debt to see their share of outstanding debt in the nonfinancial corporate sector rise from 25 per cent in 2013 to 30 per cent in 2016 (World Bank 2017). In part, this was because the government temporarily lifted the restraint on LGFV borrowing in mid-2015 when economic growth slowed drastically. Ironically, because the debt reclassification exercise had removed a good deal of debt from the balance sheets of LGFVs, many were now in an improved position to borrow, and were unconstrained by the cap on government borrowing as their debt was, under the new Budget Law, not counted as government debt. One estimate has LGFV bonds reaching RMB47 trillion in June 2017-nearly three times the total local government debt recorded in the MOF monitoring system (Yu et al. 2018).

Second, local governments have continued to find hidden ways to borrow, including new ones such as public-private partnerships and service procurement contracts. Other methods are not so new: borrowing from SOEs, LGFVs and local banks and pushing fiscal expenditures on to them, non-payment of construction contracts, and so on (Yu et al. 2018). The numerous problems exposed by MOF inspections and by the National Audit Office (NAO) came to the top leadership's attention by mid-2016, culminating in the 'Plan for Emergency Response to Local Government Debt Risks', issued by the State Council in October 2016, which required all 
local governments to set up a Leading Group for Debt Management and assign responsibilities for strengthening monitoring and preparing emergency responses (State Council 2016). In April and May 2017, a package of decrees was issued jointly by the MOF, NDRC, People's Bank of China (PBC), China Banking Regulatory Commission (CBRC), China Securities Regulatory Commission (CSRC) and the Ministry of Justice, setting out further responsibilities of local governments for monitoring and assigning accountability not only for direct debt, but also for contingent debts, and again stressing that LGFVs must be delinked from government finances. The MOF issued several more directives in 2017 reiterating the prohibition of off-budget borrowing and the use of LGFVs for borrowing.

The one bright spot has been the growth and development of a market for government securities, including local government bonds. Over time, this may become a normal channel for local government borrowing. According to the MOF's accounts, 90 per cent of the local government debt currently reported is held in government bonds. While they are still not market-based, this may change over time.

\section{Conclusion}

The fiscal reforms initiated by then finance minister Lou Jiwei were comprehensive in scope and extremely far reaching. They set about building infrastructure for budget management that is better able to support the increasingly large and complex public sector in China, which rivals the size of the US Federal Government in annual spending. When completed, the new government financial reporting system will provide detailed information on the true size and operations of the public sector that will support more sophisticated whole-of-government analyses. Accompanied by stringent disclosure rules and improved accounting standards, the system will provide higher-level governments with the information base for designing improved intergovernmental arrangements - the ultimate goal of Lou's reform package.

In this review, I have identified significant progress towards installing the GFRS. More importantly, I believe the process of collecting and scrutinising the financial claims of all state-owned entities on the budget has also set in motion a new dynamic that will gradually lead to a clarification of the boundary between the state and the market, as local governments have greater incentive to loosen their ties to SOEs to reduce the administrative burden of reporting as well as to improve the government's balance sheet to make room for new debt. The remarkable increase in transparency in local government financial reporting will enhance the ability of higher levels to hold local governments accountable and reduce opportunities for the diversion of funds. Putting this information into the public sphere will also create greater potential for public participation in budgeting, whether intended or not. 
These reforms are just starting, however, and their progress is fragile and could easily be reversed. The failure of debt containment provides a perfect illustration of the uselessness of building structures when rules can be circumvented or are not enforced. Even though a national registry of local government debt has been in operation since 2015-along with an early warning system for fiscal risks - to date, they are but empty shells, as they are unable to track hidden debt and do not count the contingent liabilities of LGFVs.

The experience of the past five years has confirmed the enormous difficulty of, and the long road ahead for, fiscal reform, which must compete with other macroeconomic concerns (such as the rate of growth) and powerful vested interests. The recent appointment of Liu Kun as finance minister signals that fiscal reform will continue in Xi Jinping's second term. With the focus turning to intergovernmental reform and doubling down on efforts to contain local government debt, Liu's experience in Guangdong should prove particularly useful since the province has been a leader in performance management and debt resolution. ${ }^{17}$ While hoping for a supportive policy environment for fiscal reform, Minister Liu would do well to fast-track a program of capacity-building in the MOF and subnational finance bureaus. This new system is administratively far more demanding than the one being replaced, and will require higher-level skills.

\section{References}

21st Century Economic Herald (2017), The Central Leading Group for Comprehensively Deepening Reform approved the work plan to compile national and local balance sheets, [in Chinese], 21st Century Economic Herald, 27 June. Available from: www.cb.com.cn/economy/2017_0627/1188687.html.

Beijing Municipal Bureau of Statistics (BMBS) (2014), Beijing Statistical Yearbook 2014, Beijing: China Statistics Press.

Beijing Municipal State-owned Assets Supervision and Administration Commission (SASAC) (2015), Website, [in Chinese]. Available from: www.bjgzw.gov.cn/qt/ forepageview/gzhy/gzhy15.jsp.

Fock, A. and Wong, C. (2008), Financing rural development for a harmonious society in China: Recent reforms in public finance and their prospects, World Bank Policy Research Working Paper 4693, August, Washington, DC: The World Bank.

17 Liu headed the debt resolution in the bankruptcy of the Guangdong International Trust and Investment Corporation in the late 1990s (Times Weekly 2018). 
Han, J., Li, G. and Yuxin, H. (2014), Deep changes that affect the modernization of the nation's governance system: Minister of finance Lou Jiwei explains the overall program for deepening reform of the fiscal system, Xinhua, 4 July.

International Monetary Fund (IMF) (2015), Government Finance Statistics Manual 2014, Washington, DC: IMF.

Lin, W. and Wong, C. (2012), Are Beijing's equalization policies reaching the poor? An analysis of direct subsidies under the 'three rurals' (Sannong), China Journal 67(January). doi.org/10.1086/665738.

Liu, L., Pradelli, J. and Zhao, M. (2015), International experience on subnational financial reporting for managing fiscal risks, World Bank Policy Note (Draft), Washington, DC: The World Bank.

Liu, M. (2017), An important promoter of 'transparent government': A special inspection of local budgets and final accounts open a 'window' for the public, China Finance and Economics News, 1 March. Available from: www.mof.gov.cn/ zhengwuxinxi/caijingshidian/zgcjb/201703/t20170301_2544207.html.

Liu, M., Wang, J., Tao, R. and Murphy, R. (2009), The political economy of earmarked transfers in a state-designated poor county in western China: Central policies and local responses, The China Quarterly 200(December): 973-94. doi.org/10.1017/S0305741009990580.

Lou, J. (2014), Deepening reform of the fiscal and tax system to build a modern system of public finance, [in Chinese], Qiushi 20(13 October).

Ministry of Education (MOE) (2016), Chinese Education Statistical Yearbook, Beijing: China Statistics Press.

Ministry of Finance (MOF) (2014), China Accounting Yearbook 2014, Beijing: MOF.

Ministry of Finance (MOF) (2015a), Notification on launching a special inspection of the situation of local budget disclosures, [in Chinese], Doc. 84, Supervision and Inspection Bureau, 20 October, Beijing: MOF.

Ministry of Finance (MOF) (2015b), Notification on the issuance of government financial reporting methodology (trial), MOF Doc. 212, 16 November, Beijing: MOF.

Ministry of Finance (MOF) (2016a), Bulletin on inspection of local budget and final accounts and NEV subsidies, [in Chinese], 8 September, Beijing: MOF Press Office. Available from: www.mof.gov.cn/zhengwuxinxi/bulinggonggao/ tongzhitonggao/201609/t20160908_2413434.htm. 
Ministry of Finance (MOF) (2016b), Notice on conscientiously doing a good job on local government budget disclosures, [in Chinese], MOF Doc. 123, Beijing: MOF. Available from: yss.mof.gov.cn/zhengwuxinxi/zhengceguizhang/201609/ t20160924_2426035.html.

Ministry of Finance (MOF) (2016c), Operating procedures for local government budget disclosures, [in Chinese], MOF Doc. 143, Beijing: MOF. Available from: www.mof.gov.cn/gp/xxgkml/yss/201611/t20161121_2510868.html.

Ministry of Finance (MOF) (2018a), Circular of the Ministry of Finance on revising and printing the 'guidelines for the preparation of financial reports for government departments (trial)', [in Chinese], MOF Doc. 29, 1 March, Beijing: MOF. Available from: www.weichicaiwu.com/law/4258.html.

Ministry of Finance (MOF) (2018b), Notice of the Ministry of Finance on launching the pilot work of 2017 government financial report compilation, [in Chinese], MOF Doc. 34, 12 March, Beijing: MOF. Available from: www.waizi.org.cn/ doc/31883.html.

National Audit Office of China (NAO) (2017), Report of the Ministry of Finance on resolutely stopping local governments illegally raising debt, [in Chinese], 12 December, Wall Street News. Available from: wallstreetcn.com/ articles/3051249.

National Bureau of Statistics (NBS) (2014), China Statistical Yearbook 2014, Beijing: China Statistics Press.

National People's Congress (NPC) Standing Committee (2014), Decision on revising the 'People's Republic of China Budget Law', [in Chinese], 31 August, Beijing: NPC of the People's Republic of China. Available from: www.npc.gov.cn/npcl xinwen/2014-09/01/content_1877061.htm.

State Council (2014a), Opinion on strengthening management of local government debt, Doc. 43, 21 September, Beijing: State Council.

State Council (2014b), Reform plan for building the comprehensive financial reporting system using accrual accounting, [in Chinese], Doc. 63, 12 December, Beijing: State Council.

State Council (2016), Plan for emergency response to local government debt risks, [in Chinese], Office of the State Council Letter No. 88, 27 October, Beijing: State Council.

Times Weekly (2018), Finance Minister Liu Kun's past in Guangdong, [in Chinese], Times Weekly, 27 March. Available from: news.sina.com.cn/c/2018-03-27/docifysrpxk6278916.shtml. 
Wong, C. (1993), Public Finance and Economic Decentralization, in W. Galenson (ed.), China's Economic Reform in the 1990s, Ann Arbor: University of Michigan Press.

Wong, C. (2005), Public sector budgeting issues in China, in Organisation for Economic Co-operation and Development (OECD), Governance in China, Paris: OECD Publishing.

Wong, C. (2009), Rebuilding government for the 21st century: Can China incrementally reform the public sector?, China Quarterly 200(December). doi.org/10.1017/S0305741009990567.

Wong, C. (2010), Fiscal reform: Paying for the harmonious society, China Economic Quarterly 14(2): 22-7.

Wong, C. (2011), The fiscal stimulus program and problems of macroeconomic management in China, OECD Journal on Budgeting 11(3): 1-24. doi.org/ $10.1787 /$ budget-11-5kg3nhljqrjl.

Wong, C. (2012), Toward building performance-oriented management in China: The critical role of $M \sigma E$ and the long road ahead, ECD Working Paper Series No. 27, September, Washington, DC: World Bank Independent Evaluation Group.

Wong, C. (2013a), Paying for urbanization: Challenges for China's municipal finance in the 21st century, in R. Bahl, J. Linn and D. Wetzel (eds), Metropolitan Government Finances in Developing Countries, Cambridge, MA: Lincoln Institute for Land Policy.

Wong, C. (2013b), Reforming China's public finances for long-term growth, in R. Garnaut, C. Fang and L. Song (eds), China: A new model for growth and development, Canberra: ANU E Press. doi.org/10.22459/CNMGD.07.2013.10.

Wong, C. (2016), Budget reform in China: Progress and prospects in the Xi Jinping era, OECD Journal on Budgeting 15(3): 27-36. doi.org/10.1787/budget-155 jm0zbtm3pzn.

Wong, C. and Bird, R. (2008), China's Fiscal System: A Work in Progress, in L. Brandt and T. Rawski (eds), China's Great Transformation: Origins, Mechanism and Consequences of the Post-Reform Economic Boom, New York: Cambridge University Press.

World Bank (2002), China: National Development and Sub-national Finance, a Review of Provincial Expenditures, Report No. 22951-CHA, April, Washington, DC: World Bank. 
World Bank (2007), China: Public services for building the new socialist countryside, Report No. 40221-CN, Washington, DC: The World Bank.

World Bank (2017), China Economic Update-December 2017: Growth, resilience and reform momentum, 19 December, Washington, DC: The World Bank.

Xi, J. (2013), An explanation of the Chinese Communist Party Central Committee decision on several major questions about deepening reform, [in Chinese], Xinhua, 15 November. Available from: news.xinhuanet.com/politics/201311/15/c_118164294.htm.

Xinhua (2017a), National Bureau of Statistics answers reporters' questions on the programme for national and local balance sheet preparation, [in Chinese], Xinhua, 31 October. Available from: www.xinhuanet.com/fortune/201710/31/c_129729861.htm.

Xinhua (2017b), Government finance reports can be checked and supervised in Jiangsu, Xinhua Daily, 11 November. Available from: news.sina.com.cn/o/201711-07/doc-ifynmnae2405315.shtml.

Yu, H., Wang, X. and Teng, J. X. (2018), China battles hidden local government debt, Caixin Global, 11 March. Available from: www.caixinglobal.com/201803-11/china-battles-hidden-local-government-debt-101219793.html.

Zhang, Y. S. and Barnett, S. (2014), Fiscal vulnerabilities and risks from local government finance in China, IMF Working Paper No. 14/4, January, Washington, DC: International Monetary Fund. 
This text is taken from China's 40 Years of Reform and Development: 1978-2018, edited by Ross Garnaut, Ligang Song and Cai Fang, published 2018 by ANU Press, The Australian National University, Canberra, Australia.

doi.org/10.22459/CYRD.07.2018.15 